\title{
DESKRIPSI TENTANG KHOTBAH YANG BERKUASA SECARA ALKITABIAH
}

\author{
Mortan Sibarani, MM, M.Pd.K \\ Sekolah Tinggi Teologi Injili Arastamar (SETIA) Jakarta \\ msibarani@sttsetia.ac.id
}

\begin{abstract}
Abstrak
Khotbah di dalam ibadah Kristen adalah menjadi suatu yang terpenting dan terutama dari semua rangkaian ibadah. Baik di gereja maupun di persekutuan umat Kristen. Khotbah merupakan pusat dalam ibadah Kristen. Berkhotbah adalah sebuah tugas rohani yang penting dan mulia. Khotbah adalah suatu proses yang membangun pengkhotbah dan jemaat, tidak ada penjelasan yang seolah bisa menangkap kedinamisan ini. Untuk itu \seorang pengkhotbah adalah seorang yang dipanggil Tuhan dan dipercayai umat Tuhan untuk menjelaskan firman-Nya.
\end{abstract}

\section{PENDAHULUAN}

Khotbah di dalam ibadah Kristen adalah menjadi suatu yang terpenting dan terutama dari semua rangkaian ibadah. Baik di gereja maupun di persekutuan umat Kristen. Khotbah merupakan pusat dalam ibadah Kristen. Berkhotbah adalah sebuah tugas rohani yang penting dan mulia. Khotbah adalah suatu proses yang membangun pengkhotbah dan jemaat, tidak ada penjelasan yang seolah bisa menangkap kedinamisan ini. Untuk itu \seorang pengkhotbah adalah seorang yang dipanggil Tuhan dan dipercayai umat Tuhan untuk menjelaskan firman-Nya.

1. Definisi Khotbah

Untuk memahami dan mengerti bagaimana mempersiapkan suatu khotbah yang berkuasa maka perlu mengetahui pentingnya berkhotbah. Istilah khotbah berasal dari kata sifat Yunani "homiletika. Kata "homiletika" berasal dari kata kerja bahasa Yunani "Homilein" artinya "bercakap-cakap'?", kalirnat ini disebutkan empat kali dalam perjanjian baru, seperti Kisah Para Rasul 24:26, Yohanes 4:27, Matius 24:3, sedangkan dalam Lukas 24:14-15 berbunyi: Dan mereka bercakap-cakap tentang segala sesuatu yang telah terjadi. Ketika mereka sedanq bercakap-cakap dan bertukar pikiran, datanglah Yesus sendiri mendekati mereka, lalu berjalan bersama- sama dengan mereka.

Dari kata ini, timbul kata sifat "homiletika" yang selalu dihubungkan dengan kata "technell jadi techne homiletika artinya II ilmu pergaulan atau ilmu bercakapcakap" Homiletika berhubungan dengan cara bagaimana firman Tuhan (Alkitab) yang menyelamatkan itu disampaikan. P.H. POUW, dalam bukunya yang berjudul "Uraian Singkat Tentang Homiletik", menyatakan bahwa :

Kata homiletik berasal dari kata Gerika "Homilia" yang berarti perundingan, penguraian atau khotbah. Dalam bahasa Indonesia, saya terjemahkan dengan ilmu berkhotbah atau pelajaran berbicara di hadapan orang banyak. Homiletik itu pelajaran bangsa barat, tetapi sebenarnya berasal dari benua timur yakni bangsa Israel. Hal ini terlukis dengan nyata dalam kitab SUCi. 
Dalam perkembangannya, ilmu ini kemudian dihubungkan dengan khotbah gerejawi. Homiletika dihubungkan dengan firman Tuhan yang menyelamatkan dan disampaikan dalam suatu pembicaraan yang menerangkan jalan keselamatan manusia melalui Tuhan Yesus Kristus, disampaikan melalui manusia, supaya menjadi kesaksian bagi manusia yang lain. Sedangkan Hasan Sutanto dalam bukunya "Homiletik Preaching dan Metode Berkhotbah" menyatakan bahwa,

"Definisi khotbah menjadi berbeda di mata ahli yang berbeda, ... definisi khotbah sangat tergantung pada teologi yang diyakini orang yang bersangkutan. Selain teologi, unsur-unsur lain seperti bahasa, latar belakang dan budaya juga ikut menentukan pemahaman sesorang akan khotbah.... Dalam perjanjian baru terdapat beberapa kata yang mempunyai arti "berkhotbah", kata-kata ini diterjemahkan dengan kata "memberitakan" (bdk. Mrk. 1:14). Namun penyelidikan atas arti kata ini tidak memberikan gambaran yang cukup jelas tentang pelayanan berkhotbah. Itu sebabnya yang perlu diperhatikan adalah kebaktian orang Yahudi di dalam Sinagoge, khususnya praktik berkhotbah.

Jadi, khotbah itu berhubungan kebaktian di sinagoge orang Yahudi dan kebaktian orang Kristen. Hubungan ini tidak perlu diherankan, sebab orang Kristen angkatan pertama terdiri atas orang Yahudi. Pada abad awal, rasul-rasul pun menghadiri pertemuan atau kebaktian di sinagoge (Sdk. Yakobus 2:1-8). Begitu juga rasul Paulus pemah aktif menyampaikan berita di sinagoge (Sdk. Kisah Para Rasul 9:20; 13:14-15). Yuyung Nehemia mengatakan bahwa,

"Berkhotbah ialah memberikan kabar kesukaan tentang Allah dan kehendakNya, yang dilakukan oleh orang yang terpanggil serta yang dipimpin oleh Roh Kudus yang ditujukan kepada manusia untuk memenuhi kebutuhan mereka dan mendorong mereka untuk mengambil keputusan".

Dengan demikian, berkhotbah adalah sebuah tugas yang berat, sebab yang diandalkan dalam pelayanan ini bukanlah kekuatan dan kepintaran manusia.tetapi kuasa Roh Kudus. Pengkhotbah harus melayani dengan motivasi yang murni. Hatinya semata-mata ingin memuliakan nama Tuhan. Selain memberitakan firman Tuhan di atas mimbar, dia pun dituntut menjadi pelaku ajaranNya. Karena pengkhotbah adalah teladan bagi pendengarnya.

\section{Sejarah Khotbah}

Hasan Sutanto dalam bukunya mengatakan, "Pelayanan berkhotbah mempunyai sejarah yang panjang, menyatakan bahwa praktik khotbah telah berlangsung sebelum hadirnya agama Kristen".

Setidaknya berkhotbah mulai muncul pada tradisi ibadah Yahudi. Itu pun terjadi setelah berlangsung krisis identitas karena berbagai peristiwa pembuangan. Akibat tragedi pembuangan itu, sebagian besar generasi muda tak lagi mampu memahami teks-teks Ibrani dengan baik. Di sisi lain, para pemimpin pun tetap ingin mempertahankan penggunaan bahasa Ibrani sebagai tradisi luhur mereka. Kenyataan ini mendorong para pemimpin menerjemahkan dan menjelaskan teks-teks suci yang mereka baca (kumpulan hasil penjelasan itu disebut targum). Upaya ini melahirkan apa yang sekaranq kita kenai sebagai khotbah. Oi hal ini, khotbah dimengerti sebagai upaya menjelaskan makna teks kepada pendengarnya. 
Kekristenan awal yang memang pertama-tama menerima tradisi Yahudi (termasuk ibadah), turut melanjutkan tradisi penjelasan teks itu.

Hanya yang berbeda adalah penjelasan itu lebih ditujukan kepada katekumen (peserta katekisasi yang mau menjadi Kristen). Yaitu agar mereka semakin memahami kitab suci dengan baik sehingga imannya tidak mudah diombangambingkan oleh berbagai pengajaran yang sesat, karena pengajaran sesat banyak diberitakan pada waktu itu. Maka itu khotbah dipahami perannya lebih sentral, yaitu sebagai media pembinaan jemaat. Sehingga jemaat memiliki dasar yang kuat untuk dapat mengatasi pengajaran sesat lewat khotbah-khotbah yang disampaikan.

Perkembangan besar terhadap praktik khotbah terjadi ketika Injil mulai diberitakan di kalangan orang-orang Yunani. Dalam dunia Yunani-Romawi, retorika (ilmu pidato) telah berkembang dengan pesat. Nama Aristoteles dan Cicero serta banyak lagi yang lain dikenal sebagai orator-orator ulung. Perjumpaan de gan prinsip-prinsip retorika ini turut mempengaruhi bentuk khotbah gereja. Khotbah kemudian dipahami tak hanya sebagai media pembinaan, tetapi juga media solusi atas sebuah persoalan dan juga perdebatan umum. Dengan demikian, unsur keindahan kata-kata menjadi sangat penting. Sedangkan Hasan Sutanto mengatakan tentang sejarah khotbah yaitu :

"Pada zaman perjanjian lama, para nabi orang Yahudi sudah memberikan contoh bagaimana berkhotbah dengan berani dan berapi- api. Walaupun pemberian khotbah tidak mengambil peranan penting dalam ibadah di bait suci, tetap,i rabi dan ahli Taurat telah meneruskan tradisi berkhotbah di sinagoge dengan menjelaskan Alkitab kepada bangsanya."

Pada abad pertama gereja menerima kekayaan ilmu berkhotbah Ibrani, khususnya dalam hal berkhotbah berdasarkan Alkitab. Pada masa awal, karena jemaat masih kecil dan kebanyakan anggota jemaat masih terdiri atas orang Yahudi, penyampaian khotbah masih berpola sederhana. Situasi menjadi berubah ketika kabar baik juga diberitakan kepada orang non- Yahudi. Oi antara orang Kristen baru ini ada yang sudah mengenal retorika Yunani dan Latin.

Bersamaan dengan jalannya waktu dan perubahan situasi, ilmuberkhotbah orang Kristen berkembang untuk menjawab tantangan yang berasal dari luar gereja dan kebutuhan yang berasal dari dalam gereja. Melalui khotbah gereja mengabarkan Injil, membina rohani dan moralitas umat atau memberikan apologetika kepada masyarakat yang tidak simpatik.

Pada abad ke- 4 dan 5, homiletik mengalami kemajuan karena agama Kristen diakui kerajaan Romawi, tokohnya seperti: Chrysostom, Ambrose dan Agustinus. Oalam era ini, muncullah berbagai pengkhotbah besar yang sukar tertandingi kemampuannya. Misalnya Yohanes Chrysostomus, yang namanya berarti Yohanes si mulut emas. Mereka memberikan sumbangsih besar bagi pelayanan berkhotbah. Sedangkan pada masa abad pertengahan tidak mendapat kemajuan yang berarti, hal ini dilihat dari khotbah-khotbah yang disampaikan. lsi khotbahnya dipenuhi dengan hal-hal yang kurang relevan, bahkan yang bersifat takhayul, sehingga menjadikan pendengarnya kurang bergairah.

Pada abad ke 15 , bersamaan dengan bangkitnya kalangan humanis terhadap bahasa Yunani dan latin kuno, muncul pula kritik mereka terhadap metode Skolastik. Oiantaranya Oesiderius Erasmus yang memberi kontribusi besar terhadap ilmu 
khotbah. Juga John Colet yang menaruh perhatian akan eksposisi Alkitab. Alkitab mulai dijadikan sebagai dasar khotbah. Kemudian tibalah masa reformasi, Alkitab makin di hormati. Khotbah di sampaikan dalam bentuk sederhana. Memang tidak satu pun reformis, termasuk Martin Luther dan John Calvin yang menulis buku khusus tetang hal berkhotbah. Namun mereka sangat mementingkan khotbah yang berpusat kepada Alkitab. Di antara para reformis pun ada yang memberikan saran penting tentang pelayanan ini.

Pada abad ke 17 dan 18, metode Skolastik kembali diminati isi khotbah menjadi kurang berkaitan dengan kebutuhan masyarakat. Walaupun demikian, masih ada buku-buku homiletik yang cukup penting diterbitkan. Oi antaranya, karya yang di tulis Jean Claude PO_ilirD> oddridge dan Catton Mather. Pada abad ke-18, pelayanan John Wesley manandakan mulainya kebangunan rohani di Eropa. Oi New England ada Jonathan Edwards dan George Whitefield yang memberikan khotbah yang mempesonakan para pendengar. Kebangunan rohani ini di sertai dengan upaya pengabaran injilsampai ke ujung dunia. Ada perhatian terhadap kehidupan lapisan masyarakat yang selama ini diabaikan. Pada abad 19, ilmu pengetahuan dan buku -buku bertambah pesat, termasuk buku teori berkhotbah dapat dicetak dalam jumlah yang besar. Memang pada abad ini ilmu homiletik tidak berkembang karena munculnya ide-ide baru. Tetapi ada tendensi khotbah di sampaikan dengan cara yang lebih informal, menarik dan bervariasi. Pada rentang waktu ini Alexander Vinet menulis sebuah buku homiletik yang kemudian mempengaruhi John A. Broadus. Lalu John A.Broadus sendiri menulis buku sejenis yang sangat terkenal di AS.

Pada abad itu dunia menyaksikan William Booth yang memulai Salvation Army, mendengarkan khotbah yang disampaikan Charles H.Spurgeon dan Charles G.Finney dan dari sisi lain duniapun menyaksikan munculnya dan berkembangnya berbagai analisis Alkitab yang kritis. Dua macam perkembangan yang bertolak berlakang ini sama-sama hadir dalam abad itu.

Abad ke-20 adalah abad yang penuh dengan perubahan dan kemajuan yang dahsyat. Dua kali perang dunia telah menyebabkan korban jiwa yang begitu besar' dan kerugian yang tak terhitung. Penderitaan rakyat amat sulit di lukiskan dengan kata-kata. Selesainya perang dunia ke-2 di ikuti perubahan besar dalam politik internasional. 8anyak bangsa beroleh kemerdekaan. Sayangnya, di negara tertentu terjadi penekanan yang hebat atas gereja karena sistem politiknya. Bumi ini seperti dibelah menjadi dua kubu besar yang masing-masing di pimpin oleh Amerika Serikat dan Uni Soviet. Dunia barat termasuk Amerika dan Jepang beroleh kemajuan ekonomi yang menakjubkan. Di lain pihak Uni Soviet serta sekutusekutunya akhirnya tidak dapat mempertahankan sistem politik mereka. Amerika tampil sebagai negara yang mendominasi dibanyak bidang.

Pada abad ke-20, banyak negara dapat meningkat standar kehidupan rakyatnya tetapi peningkatan tidak merata. Masih ada sekian negara yang di Asia, Amerika latin, khususnya di Afrika masih sangat tertinggal. Perkembangan ekonomi global yang tidak merata ini menyebabkan kesenjangan yang makin besar di antara negara maju dan berkembang. Abad ini juga di tandai dengan kemajuan teknologi yang luar biasa. Manusia dikirim ke luar angkasa. Hampir setiap hari ada penemuan baru, transportasi makin mudah, jaringan telepon, televisi, dan internet telah menyatukan penghuni bumi. Data dan informasi dapat dikirim dengan mudah, cepat dan murah. Bersamaan dengan ini penduduk dunia terus bertambah khususnya di negara berkembang.Di banyak negara terjadi urbanisasi yang hebat. Budaya masyarakat 
pertanian dan pedesaan diganti dengan pola kehidupan metropolitan. Pengunjung gereja di kota kecil dan desa menjadi berkurang, sedangkan di kota besar gereja harus mengumpulkan dana yang tidak sedikit untuk membangun gedung gereja. Jemaat di Amerika Utara dan Korea, sejalan dengan kemajuan ekonomi dan kemudahan transportasinya, sanggup membangun gedung gereja yang super besar. Eksposisi Alkitab sangat diperhatikan, sehingga Alkitab menjadi pusat khotbah, tokohnya sepertiDesiderius Erasmus.

Dalam situasi seperti ini gereja berhadapan langsung dengan sekularisme dan materialisme. Selain memberi petunjuk rohani, gereja juga harus menjawab berbagai pertanyaan yang timbul karena masalah keadilan, kemiskinan, etika dan penemuan baru di bidang teknologi. Dengan bangkitnya dan makin kokohnya nasionalisme, gereja masing-masing negara ingin hidup sendiri. Ini ditandai dengan munculnya pengkhotbah-pengkhotbah yang melayani dengan gaya khas di masingmasing negara. Dibandingkan dengan benua Eropa, jumlah orang Kristen bertambah lebih cepat dibeberapa negara di Asia, Amerika Latin dan Afrika. Dan kini orang Kristen yang ada di wilayah-wilayah ini sudah lebih banyak dari pada saudara seimannya di Eropa dan Amerika Utara. Namun demikian pada dasarnya peta agama dunia tidak banyak berubah.

Di bidang pengabaran Injil, persiapan dan organisasi yang dilakukan lembaga misi makin rapi. Ada kebaktian besar yang diadakan di luar gedung gereja. Karena sebagian negara sudah meninggalkan revolusi industri, dan masuk ke area komunikasi, maka khotbah dan beribadah -dengan menggunakan media elektronik menjadi makin popular. Kabar baik dapat disebarkan dengan mudah melalui buku, radio-dan televisi. Teologi dan gaya berkhotbah para pengkhotbah, termasuk yang berkhotbah di TV makin bervariasi. Melihat pengaruh besar yang di berikan televisi, generasi akhirabad ke-20 mungkin layak disebut sebagai generasi TV. Gerakan karismatik menulis lembaran baru dalam hal ibadah, pujian, dan berkhotbah. Bersama dengan kehidupan bermasyarakat yang makin terbuka dan bervariasi, dunia teknologi juga diramaikan dengan berbagai teologi, diantaranya teologi pembebasan, teofogi feminin, dan teologi makmur.Kalau melihat perkembangan homiletik abad ke-20 dengan lebihcermat, boleh dikatakan pada abad itu khotbah topikal sangat diminati. Kemudian, perhatian dialihkan kepada hubungan antara khotbah dengan teologi, dan selanjutnya struktur khotbah. Alkitab dihormati sebagai dasar khotbah. Khotbah ekspositori dan tekstual menggantikan posisi topikal. Pada tiga puluh tahun akhir abad ke-20 banyak pengkhotbah yang tidak begitu puas dengan struktur khotbah dan gaya berkhotbah tradisional. Itu sebabnya ada sebagian pengkhotbah mulai menaruh minat kepada khotbah narasi. Struktur khotbah dan gaya berkhotbah yang beraneka ragam ini memperkaya duniahomiletik. Gaya konservatif hidup berdampingan dengan gaya berkhotbah yang begitu emosional. Ada banyak nama pengkhotbah dan sarjana homiletika abad ke-20 yang patut disebutkan di sini...Namun daftar nama ini akan sangat panjang, jika semua nama ini harus disebutkan satu persatu. Yang jelas tokoh-tokoh ini telah memberikan berbagai sumbangsih kepada pelayanan berkhotbah. Diantara mereka terdapat Billy Graham yang sering dipuji sebagai penginjil yang konservatif, bermoral dan konsisten.

Sejarah memang memberi kita banyak pelajaran. Salah satu pelajaran adalah perkembangan homiletik mempunyai hubungan erat dengan perkembangan gereja. Pada saat pelayanan khotbah dihormati dan diperhatikan, orang Kristen pun akan 
menghormati dan memperhatikan firman Tuhan. Pertumbuhan gereja secara kualitas dan kuantitas sangat ditentukan oleh pelayanan di atas mimbar. Dengan mengamati homiletik seorang akan mengenal berapa serius gereja melakukan pelayanan misi. Homiletik juga mempunyai hubungan erat dengan ilmu penafsiran dan teologi. Tanpa menafsirkan Alkitab dengan sungguh-sungguh, sulit diharapkan ada isi khotbah yang bermutu. Teologi menentukan, tetapi semangat berkhotbah harus diperhatikan. Khotbah menjadi media efektif menyampaikan teologi. Sejarah juga menunjukkan bahwa homiletik merefleksikan interaksi gereja dengan masyarakat yang ada disekitarnya. Gereja yang peduli terhadap masyarakat dan kebutuhannya, akan menyatakan kasihnya melalui khotbah. Melalui khotbah, gereja menuntun mereka yang bimbang, menghibur mereka yang patah semangat, dan membela mereka. Sejarah gereja juga mengajar para pengkhotbah segala abad tentang kunci kesuksesan para pendahulu yang telah melayani dengan setia dan efektif pada zamannya. Sejarah juga membuktikan kepada umat Tuhan bahwa Dia lah penguasa sejarah manusia. Tuhan lah yang membangkitkan hamba-hamba-Nya menjawab tantangan dan kebutuhan setiap zaman.

Pada umumnya pemimpin rohani atau yang lebih khusus, pengkhotbahpengkhotbah menjadi motor bagi pembaharuan dan kebangunan rohani. Tokohtokoh ini telah memberi dampak yang begitu positif dan lama bagi gereja bahkan masyarakat yang ada di luar gedung gereja. Tetapi yang tidak kalah penting adalah sejarah juga memberi peringatan yang keras dan jujur kepada segenap hamba-Nya. Pengkhotbah yang begitu tenar dan komunikatif dapat jatuh kedalam dosa yang sangat memalukan. Apa yang dibuat oleh orang-orang ini menjadi bahan tertawaandikalangan orang tidak percaya. Gereja Tuhan sangat dirugikan. Apa yang pernah terjadi dalam sejarah dapat terjadi lagi pada zaman sekarang dan zaman yang akan datang. Itu sebabnya biarlah semua pelajaran ini, manis dan pahit menjadi dorongan dan peringatan bagi gereja pada umunya, dan khususnya bagi setiap orang yang terpanggil melayani diatas mimbar.

\section{Pentingnya Khotbah}

Berkhotbah adalah pelayanan penting dalam kehidupan bergereja. Maka itu setiap khotbah harus mempunyai maksud atau tujuan. Tujuan adalah sesuatu yang diharapkan oleh pengkhotbah untuk dilakukan oleh pendengarpendengarnya. P.H. POUW mengatakan bahwa :

"Seorang pengkhotbah bukan saja hanya menyediakan baik-baik isi khotbahnya, tetapi juga harus memiliki tujuan yaitu bagi Yesus Kristus dengan segala pekerjaan-Nya yang sudah genap dan sempurna. Berarti khotbah dengan ada tujuan akan dapat memuliakan Tuhan, dengan tujuan untuk memuliakan nama Tuhan bukan untuk kepentingan diri sendiri"17

Pentingnya pelayanan berkhotbah sesungguhnya sudah terbukti sejak zaman nabi di perjanjian lama, masa gereja awal, sampai pada abad selanjutnya. Sejarah gereja juga membuktikan hadirnya kebangunan rohani hampir selalu berhubungan erat dengan tampilnya seorang pengkhotbah yang dipakai Tuhan.

Pelayanan berkhotbah makin dirasakan pentingnya dalam zaman yang serba canggih. Gereja berhadapan dengan masyarakat yang makin individualistis. 
Hari minggu tidak lagi dipakai untuk beribadah, tetapiberekreaksi. Ada banyak hiburan dan kegiatan yang mengurangi minat orangKristen mendengar khotbah atau hadir dalam kebaktian. Media massa elektonik boleh menjadi alat yang efektif bagi gereja, tetapi sekaligus jugamenjadi lebih buruk, karena bahkan di kalangan Kristen ada pemimpin yang menunjukan sikap yang kurang hormat terhadap Alkitab. Ada juga sebagian orang Kristen berpendapat bahwa aksi sosial lebih berguna dari pada pelayanan lisan dari mimbar. Di Indonesia, apa yang di sebutkan di atassudah mulai di rasakan gereja. Kehidupan metropolitan yang sibuk danpandangan hidup yang meterialistis membuat sebagian urnat Tuhan tidakbegitu menarik terhadap khotbah. Ini semua menjadi tantangan dan cambuk bagi para pengkohtbah untuk melayani lebih setia dan sungguh-sungguh.

Pentingnya pelayanan berkhotbah sebagai berikut:

Pertama, berkhotbah adalah salah satu mata acara penting dalam kebaktian. Kebaktian adalah saat yang amat sakral dalam kehidupan rohaniorang Kristen. Dalam kebaktian, orang Kristen menyembah, berdoa danmemuji Tuhan. Kebaktian berhubungan erat dengan kehidupan rohani orangKristen secara pribadi dan secara bersama. Dalam kebaktian orang Kristen mendengar petunjuk Allah, berbicara kepada Allah, juga bersekutu dengansesama. Berkhotbah memang mengambil tempat penting dalam kebaktiansejak masa awal. Ketika pertemuan orang Kristen diadakan secara rutin,khotbah pun disampaikan secara teratur. (Kisah Para Rasul 2 : 42 ). Dalamliturgi kebaktian orang Kristen selalu ada penyampaian khotbah. Posisi inimakin menonjol, setelah setelah para reformasi menegaskan sifat hormat mereka kepada Alkitab (sola scriptura). Liturgi yang rumit ditinggalkan,pemberitaan firman dipentingkan. Alkitab harus diberitakan dan dipelajari karena Alkitab adalah satu-satunya petunjuk tertulis yang Allah berikan kepada manusia. Penyampaian khotbah menjadi salah satu bagian penting yang tidak dapat dipisahkan dari kebaktian orang Kristen.

Kedua, berkhotbah adalah media efektif untuk mendidik umat Kristen.

Berkhotbah dan mengajar memang berbeda. Tetapi khotbah dapat disampaikan dengan tujuan mendidik. Bahkan sering kali, khotbah merupakanmedia yang efektif untuk mendidik umat Tuhan. Sebab pada umumnya kebaktian yang diadakan pada hari Minggu adalah kesempatan dimana kebanyakan anggota jemaat hadir. Dan biasanya orang Kristen duduk dengan tenang dalam kebaktian untuk mendengarkan khotbah. Tidak jarang, ini adalah kesempatan orang Kristen mendengar ajaran Alkitab sekali selama satu minggu. Maka khotbah seharusnya di pakai dengan maksimal untuk membangun iman orang Kristen. Khotbah yang disampaikan secara sistematik dan seimbang sangat bermanfaat untuk umat Tuhan. Apa lagi khotbahdisampaikan dengan penuh kuasa dan dengan cara yangkomunikatif.

Ketiga, berkhotbah adalah kesempatan baik memberikan apologetika. Apologetik dibutuhkan waktu gereja berhadapan dengan masyarakat yang bersifat tidak bersahabat. Dalam keadaan demikian, kesalahpahaman sering tidak dapat dielakan. Kesalahpahaman ini menjadi serius jika ada pihak-pihak tertentu dengan sengaja atau tidak sengaja melontarkan komentar-komentar yang subjektif atau fitnah terhadap orang Kristen. Situasi ini akan menimbulkan ketegangan dan kerugian yang tidak perlu. Hal seperti ini sudah acap kali terjadi dalam sejarah, juga pada zaman modern. Salah saturespon yang dapat di berikan gereja adalah apologetika yang di sampaikanmelalui khotbah. Khotbah adalah pembelaan dari 
pihak gereja yang menjernihkan kesalahpahaman, meneduhkan situasi, dan mengajak pihak yang tidak bersahabat melihat keadaan yang sesungguhnya.

Keempat, berkhotbah dapat menjangkau mereka yang belum percaya. Khotbah dapat menjangkau mereka yang belum percaya kepada Tuhan Yesus. Catatan khotbah Petrus di pasal kedua dalam kitab Kisah Para Rasul adalah khotbah yang sangat menggugah. Di antara khotbah yang diberitakan Paulus dalam perjalanan penginjilannya yang menjangkau banyak daerah. Para pendengar khotbah adalah orang-orang yang samasekali belum pernah mendengar kabar baik. Sebenarnya kabar baik bukansaja perlu diberitakan dilingkungan orang non-Kristen. Di lingkungan dimanaorang menamakan dirinya Kristen pun perlu diadakan pengabaran Injil.

Orang yang lahir dari keluarga Kristen, atau di daerah Kristen yang sudah terbiasa keluar masuk gereja tidak dengan sendirinya mengenal dan percaya kepada Tuhan Yesus. Ada saja di antara mereka yang masih berada di luariman Kristen. Itu sebabnya, khotbah yang bersifat pengabaran Injil pun perludiberitakan dalam kebaktian umum pada hari Minggu, khususnya pada hari-hari raya Kristen. Sebab tidak sedikit orang menyebut dirinya pengikut KristusYesus hanya hadir pada kesempatan seperti itu. Sayangnya, kesempatan demikian serinq _disiasiakan.Walaupun mungkin di luar dugaan sementaraorang, usaha menjangkau kelompok ini seringkali lebih sulit dibandingkan dengan usaha menjangkau orangorang yang sama sekali belum mengenal Tuhan Yesus.

Kelima, khotbah adalah cermin bagi masyarakat yang makin jauh dariTuhan. Gereja adalah hati nurani masyarakat. Gereja tidak boleh tinggal diamterhadap segala kejahatan, baik bersifat pribadi maupun yang bersifat kolektif, baik yang berskala lokal maupun yang berskala nasional. Khotbah adalah cermin yang mengajak masyarakat sadar akan segala ketidakbenaran dan ketidakadilan yang berlangsung. Jika gereja berdiam diri, ini berarti gereja tidak peduli terhadap komunitas yang ada di sekelilingnya. Sikap apatis ini hanya membuat situasi menjadi lebih buruk. Dengan dernikian gereja sudah bersalah terhadap mereka yang lemah dan tertindas. Memang gereja harus terpisah dari politik. Mimbar dalam gereja tidak boleh berubah menjadi podium politikus. Namun gereja harus berfungsi sebagai terang dan garam dalam masyarakat di mana dia berada. Sebagian fungsi ini dapat diwujudkanmelalui pelayanan bekhotbah. Khotbah dapat membantu masyarakat menentukan jalan benar yang disediakan Tuhan baginya.

Setiap khotbah harus mempunyai maksud dan tujuan, tujuan adalah sesuat yang diharapkan pengkhotbah untuk dilakukan oleh para pendengarnya. Menurut Yuyung Nehemia dalam buku Pintar Berkhotbah mengatakan, "Berkhotbah itu penting sebab menceritakan Yesus Kristus adalah keperluan, kesempatan paling besar saat ini, Menurut Alkitab dalam perjanjian baru Markus 1:38 berkata: "JawabNya: "Marilah kita pergi ke tempat lain, ke kota-kota yang berdekatan, supaya di sana juga Aku memberitakan Injil, karena untuk itu Aku telah datang."

\section{Metode Khotbah}

Dalam dunia homiletik ada metode khotbah. Metode khotbah menurut pandangan sarjana tidak sama. Salah satu sebabnya adalah kategori yang dipakai sarjana-sarjana ini tidaklah selalu sama. Seperti khotbah hari Paskah, Natal dan lainIainnya. Pengkhotbah yang mengenal Alkitab dan mengenal pendengarnya adalah pengkhotbah yang mengajarkan Alkitab dengan tepat dan komunikatif. Menurut Dr. 
Stefen Sos, dalam bukunya "Seni Berkhotbah": "Sebuah khotbah bukanlah perjalanan menyusuri seluruh kitab dalam Alkitab, melainkan suatu tikaman yang menentukan dari pedang Roh untuk mencapai tujuan tertentu. Dengan pertimbangan seperti ini, maka khotbah dapat dibagi sebagai berikut : Pertama, khotbah yang disampaikan dalam kebaktian umum di gereja. Kedua, khotbah yang disampaikan dalam kebaktian yang lebih khusus di gereja (acara khusus). Ketiga, Khotbah yang disampaikan dalam kebaktian pengabaran Injil. Khotbah yang disampaikan melalui media masa, cetak, audio dan visual. Berdasarkan metode khotbah tersebut, maka penulis akan membagi khotbah menjadi dua, yaitu :

5. Berdasarkan lsi

Dilihat dari isinya, khotbah dapat dibagi menjadi sebagai berikut:

a. Kesaksian Pribadi.

Khotbah bisa saja menceriterakan pengalaman pribadi mengenai keselamatan yang telah dialaminya. (Bdk. Markus 5:19; Mazmur. 66:16; 107:1-2; Kisah Para Rasul22; 26; II Timotius 1:12-17). Keuntungan khotbah secara pribadi yaitu :

1) Menarik. Karena orang memang suka mendengar pengalaman orang lain, apalagi kalau disampaikan dengan rendah hati dan sungguhsungguh.

2) Sering dipakai Tuhan memenangkan jiwa. Orang akan tertarik kepada Kristus kalau mendengar orang yang latar belakangnya sama dengan dirinya percaya dan diubah oleh Kristus.

3) Kesaksian tidak bisa dibantah. Orang bisa membantah suatuajaran, tetapi tidak ada yang bisa membantah suatu kesaksian yang nyata.

Bahaya khotbah secara pribadi yaitu :

1) Membuat kesaksian melebihi Firman Allah. Iman harus bersandarpada FirmanAllah, bukan pada pengalaman seseorang.

2) Bisa mendorong orang meniru pengalaman orang lain. Ini dapat menimbulkan rasa putus asa.

3) Menjadikan kesaksian itu pola bagi orang lain. Padahal Allah punya banyak cara dalam menyelamatkan orang.

4) Hanya bertumpu pada pengalaman masa lalu saja. Padahalpengalaman rohani selalu baru.

b. Khotbah berdasar peristiwa nyata maupun perumpamaan.

Menurut Hasan Sutanto: "Perumpamaan dalam Alkitab adalah cerita-cerita yang dipakai dengan maksud untuk menjelaskan suatu ajaran moral atau kebenaran rohani." Khotbah berdasarkan peristiwa/perumpamaan yaitu suatu peristiwa yang terjadi dalam Alkitab dijadikan pokok khotbah. Sementara cerita dibeberkan, artiarti rohaninya dikemukakan dan diterapkan. Tema tidak ditentukan dulu. Cerita itulah yang menjadi temanya, seperti : Kejadian 4:1-16 : tema Kain dan Habel. I Samuel 4:1-21 : tema Tabut perjanjian dirampas musuh. Lukas $17: 11-19: 10$ tema orang kusta. Keuntungan khotbah berdasar peristiwa yaitu :

1) Menarik, karena semua orang senang mendengar cerita. 
2) Membuat pendengar mengenal banyak kisah-kisah Alkitab.

3) Cerita mengandung banyak pelajaran yang bervariasi (Roma 15:4; I Korintus 10 :11). Dalam suatu cerita bisa diperoleh berbagai pelajaran sekaligus.

4) Menyediakan bahan yang cukup banyak. -Tuhan pun sering mengutip cerila-cerita perjanjian lama untuk menguatkan ajaranNya.

Bahaya khotbah berdasar peristiwa yaitu :

1) Merohanikan secara berlebih-Iebihan bagian-bagian dari cerita itu(terutama perumpamaan-perumpamaan).

2) Penyajian cerita bisa keluar batas-batas yang tidak dijamin olehAlkitab, untuk mendramatisir cerita itu.

c. Biografi

Menyelidiki kehidupan seorang tokoh Alkitab dan menarik pelajaran dari pengalaman-pengalaman hidupnya (sukses, kegagalannya dan watak). Menurut Geralds Rowland dalam tulisannya yang berjudul "Mempersiapkan sebuah khotbah Pemahaman Alkitab", mengatakan, "Biografi adalah kisah hidup seseorang. Metode ini mempelajari hidup dari beberapa tokoh yang kita temukan dalam Alkitab. Setiap biografi yang dicatat dalam Alkitab memiliki arti yang penting bagi kita, dan itu penting untuk diajarkan pada kita,,21.

Kegunaan khotbah biografi adalah :

1) Studi terbaik bagi manusia adalah manusia. b. Memikat.

2) Memberi rangsangan rohani.

3) Memberi keteladanan (I Korintus $11: 1$ ).

4) Menjadi cermin : dalam diri tokoh itu orang bisa melihat dirinya.

5) Memberi bahan khotbah yang cukup banyak.

d. Doktrin.

Doktin adalah "ajaran,,22, dalam hal ini doktrin adalah menyampaikan ajaran-ajaran pokok yang menjadi dasar kepercayaan Kristiani seperti Allah, Kristus, Roh Kudus, pertobatan, pembenaran, baptisan, kedatangan Tuhan yang kedua kali.

e. Penginjilan

Khotbah ini ditujukan kepada orang-orang yang bukan Kristen, dengan maksud membawa mereka kepada Kristus. Isinya mengajak mereka percaya kepada Kristus dan meninggalkan dosa sehingga mereka diselamatkan. Pedoman dalam penginjilan yaitu :

1) Jangan banyak ayat dan jangan menafsirkan ayat demi ayat. c. Uraikan ayat-ayat secara jelas.

2) Bila pendengar tak banyak bisa dilakukan dialog. e. Sertai kesaksian atau gambaran.

3) Tunjukkan perbedaan KeKristenan dengan agama mereka tanpa menyinggung perasaan.

4) Hindari pokok yang bisa menimbulkan perdebatan. 


\section{f. Etika}

Etika adalah "itmu tentang apa yang baik dan buruk dan tentang hak dan kewajiban moral/akhlak'P. Jadi etika adalah mengajarkantentang perilaku orang Kristen diberbagai bidang kehidupan. Yang harus diingat yaitu, khotbah jenis ini menarik, karena bersifat praktis, menyangkut kehidupan sehari-hari. Namun bahayanya, bisa menjurus kedalam moralisme, membanggakan moral yang tinggi. orang lalu berpuas diri serta yang lemah akan dilanda rasa putus asa.

Alkitab memang banyak berisi ajaran etika, tetapi ini didahului doktrin (Roma pasal 1-11. Doktrin baru disusul etika : Roma pasal 12 -15). Jadi yang indikatif dulu kemudian imperatif. Jangan terbalik dalammenyampaikannya.

\section{Khotbah Insidental Situasional.}

Kata insidental adalah terjadi atau dilakukan hanya pada kesempatan atau waktu-waktu tertentu saja, tidak secara tetap atau rutin24. Khotbah ini berdasarkan keadaan, seperti pernikahan,kematian, natal, paskah dan lain-lain. Dalam penyampaiannya harus melihat situasi, tempat dan lain-lain. Khotbah insidental ini penting sekali dilakukan dengan kuasa Allah, karena situasi ini sangatmemungkinkan untuk dapat memperkenalkan Tuhan Yesus kepadapendengarnya, sehingga dapat memenangkan jiwa bagi Tuhan. Khotbah situasional dapat juga dilakukan dengan sistem pengabaran Injil atau pendalaman Alkitab untuk memberikan informasi tentang kebenaran firman Tuhan. Karena dengan demikian, pendengarnya akan mendapat pengetahuan tentang Tuhan Yesus. Dan ini alat penting untuk memperkenalkan Tuhan Yesus kependengarnya.

\section{Berdasarkan Bentuk}

Khotbah berdasarkan bentuknya, penulis dapat membagi dalam beberapa bentuk, sebagai berikut :

\section{a. Khotbah Tekstual}

Khotbah tekstual adalah khotbah yang berdasarkan Alkitab. Menurut Geralds Rowland: "Metode ini sebagai analisa dan penjelasan dari sebuah bagian yang singkat dari kitab suci, biasanya satu ayat tunggal atau teks".Garis garis besarnya diambil dari ayat-ayat tersebut. Khotbah ini menolong pengkhotbah dan pendengar untuk memusatkan pikiran pada satu bagian Alkitab. Khotbah tekstual dapat juga disebut khotbah satu ayat sebagai pokok pembicaraan.Khotbah tekstual dimana pengkhotbah mengambil satu ayat atau sebagian dari ayat sebagai bahan khotbahnya. Tema .ditentukan, laJuayat itu diuraikan dan dibagi-bagi.

Kebaikan khotbah tekstual yaitu dimana pengkhotbah mengambil kata-kata asli dari Alkitab, lalu kata itu mendapat sorotan. Khotbah ini lebih mudah diingat karena singkat. Sedangkan keburukannya yaitu keutuhan Alkitab tidak nampak dan ayatayat yang diambil secara parsial mengesankan Alkitab kurang utuh.

b. Khotbah Topikal.

Khotbah topikal adalah "khotbah yang berdasarkan pokok atau tema"26 dan tidak secara langsung didasarkan pada satu ayat atau lebih. Khotbah ini menolong pengkhotbah untuk mengkhotbahkan kebenaran-kebenaran Alkitab. 
Khotbah ini diawali dengan memilih pokok pembicaraan (topik)tertentu, lalu mencari ayat-ayat yang sejajar untuk membahas pokoktersebut.Khotbah topikal harus memenuhi ciri-ciri sebagai berikut :

a. Keutuhan.

b. Bagian-bagiannya berkaitan satu sama lain. c. Tekanannya semakin meningkat. Kebaikan khotbah jenis lni yaitu :

a. Jemaat bisa mengenal berbagai pokok (pelajaran) Alkitab.

b. Mengesankan Alkitab sebagai suatu kesatuan.

c. Memungkinkan khotbah berseri/berangkai selama berminggu-minggu.

Keburukan khotbah topikal adalah jumlah topik terbatas, sehingga pengkhotbah bisa kehabisan bahan khotbah.

c. Khotbah Expositori

Khotbah expositori adalah khotbah yang uraiannya didasarkan pada suatu bagian yang panjang dari Alkitab secara menyeluruh dan sering kali panjangnya satu pasal atau lebih. Khotbah ini menolongorang untuk mengerti ajaran-ajaran Alkitab. Khotbah expositori adalahkhotbah yang paling baik tetapi paling sukar.

Menurut Stefen SOS, "memberi uraian menyeluruh terhadap Alkitab.Jadi dengan metode ini, kita berusaha untuk menguraikan secara terperinci makna dan kebenaran yang terkandung dalam bacaan tertentu dalam Alkitab. Metode ini mencoba untuk menunjukkan kebenaran yang sering tersembunyi di antara kata-kata pada halaman tertentu. Ini merupakan metode yang baik sekali untuk mengajarkan seluruh nasehat Allah (Kisah Para Rasul 20:27).

Kebaikan khotbah expositori yaitu :

1) Alkitabiah.Tekanan utama diletakkan pada pernyataan-pernyataan Alkitab.

2) Hal-hal yang biasanya terabaikan, mendapat perhatian (tergali)..

3) Melengkapi pengkhotbah dengan bahan khotbah untuk seumurhidup.

4) Ayat-ayat menemukan artinya yang sejati, karena tidak terlepas dari konteks.

Bahaya khotbah expositori yaitu bisa lepas dari temanya karena keasikan mengkaji tiap-tiap ayat.

\section{Peran Khotbah Yang Berkuasa}

Pengkhotbah memiliki peran yang sangat penting dalam ibadah. Inidisebabkan karena dalam khotbah, jemaat diajar untuk berjurnpa denganAllah, mengenal Allah dan mengerti kehendak Allah. Jemaat ditantang untuk bertobat; diberi penjelasan tentang bagian-bagian Alkitao yang .sulit; serta dijawab keraguannya. Melalui khotbah, Kristus diberitakan dan keselamatan diterima karena iman timbul dari pendengaran akan firman Allah.Khotbah memegang peranan yang penting, karena khotbah yang tidakdipersiapkan dengan baik, tidak akan mencapai sasaran yang memuaskan.

Sebaliknya khotbah yang kurang tersusun, bisa menjadi berkat bila penyampaiannya menarik. Jadi di sinilah kunci berhasil atau tidak berhasil sebuah khotbah. James D. Berkley (ed.), dalam bukunya "LeadershipHandbook of Preaching and Worship", mengatakan : 
"Khotbah itu memiliki kuasa, maka pendengarnya akan didorong untuk menyimaknya dan melakukan firman Tuhan yang di dengarnya. Untuk itulah seorang pengkhotbah harus memperhatikan hal tersebut, yaitu sebuah khotbah yang memiliki kuasa. Karena khotbah yang berkuasa sangat berperan penting dalam mempertumbuhkan kehidupan rohani jemaat. Khotbah yang berkuasa dapat diperoleh bila pengkhotbahnya memiliki kehidupan doa yang baik, suka belajar dan memiliki kepenuhan Roh Kudus. Karena itu, pengkhotbah harus bersungguh-sungguh menjalani hidup yang takut akan Allah. Dia perlu bekerja keras memahami makna Alkitab yang sesungguhnya. Karena banyak nyawa berada di dalam tanggung jawabnya. Bahkan kebangunan rohani dalam sejarah gereja sering dikaitkan dengan penqkhotoahnya."

Jadi peran khotbah yang berkuasa itu akan membawa pendengar untuk mendengar, memperhatikan dan melakukan firman Allah sehingga kehidupan rohani mereka bertumbuh. 